SYLWIA MOCHOCKA*

\section{Rehabilitacja osiedli mieszkaniowych}

\section{Renovation of Housing Estates}

Streszczenie

Zespoły z wielkiej płyty w Polsce cieszą się dużym zainteresowaniem wśród kupujących. Na ich wartość szczególny wpływ mają rozw azzania komy we ilości dobrze zachowanej, choc często nieuporząd owanej zieleni. Te czynniki okazują się być ważymi dla nabywców, mimo Aultan zachownia

w cella noważny rozwój sa dobrym kierunkiem działań, który może sprawdzić się w polskich warunkach, gdzie przeważaja głosy przeciw wyburzaniu obiektów z wielkiej plyty.

wać ich stan , jak i skutki nziałań do tej pory pów rehabilitacji polskich osiedll należy szczegółowo oraz na bieżąco monitorojest analizowanie przekształceń, które w tym temacie zostały przeprowadzone za granicami naszego. Tego typu analizy moga być pomocne przy podejmowaniu decyzii, co do możliwości oraz celowości wprowadzania zmian obserwowanych w Państwach sąsiednich do osiedli polskich.

\section{Summary}

Large-panel complexes in Poland are very popular among buyers. Their value is particularly affected by communication soluoften non-cultivated, green areas. These factors turn out to be important for the buyers, even though the condition of the buildings deviates from modern standards.

On the basis of selected examples of large-panel buildings and complexes, the author discussed measures undertaken to renovate them. She then drew conclusions confirming that the renovation conversions supporting sustainable developmen are a good direction of action and can work in Polish conditions, where there are opinions against the demolition of largepanel buildings

To formulate the best possible ways to renovate the Polish housing estates, it is necessary to monitor their condition, in detai and on an ongoing basis, as well as the effects of actions taken so far to upgrade them. Additionally, an important aspect is the the possibilities and advisability of introducing changes, observed in neighbouring countries, to Polish housing estates.

Stowa kluczowe: rehabilitacia, osiedla z wielkiej płtyty, zrównoważony rozwój
Key words: renovation, large-panel housing estates, sustainable developmen

\section{Wprowadzenie}

Kreowanie wspótczesnego środowiska mieszkaniowego jest niezwykle trudnym i odpowiedzialnym zadaniem. W ostatnich latach nastapiła gwałtowna zmiana warunków życia ludzi. Z jednej strony obserwujemy ciągły proces degradacji środowiska naturalnego, zanikanie terenów zielony rzecz środowiska zurbanizowanego. Natomiast z drugiej strony zmienił się stan świadomości społeczeństwa. Współczesny człowiek zauważa, że postępujące zanieczyszczenie środowiska jest przyczyną coraz liczniejszych chorób cywilizacyjnych, a kurczenie zasobów naturalnych może mieć bardzo negatywne skutki dla przyszłych pokoleń. Dodatkowo wspołczesne społeczenstwo ma wyższe wymagania co do miejsca, w którym zyje. Oczekuje od niego lepszego komfortu oraz życia w zdrowym środowisku.

\section{Introduction}

Creating a modern residential environment is an extremely difficult and responsible task. In recent years there has been a rapid change in people's living conditions. On the one hand, we observe a continuous process of degradation of the natural environment, disappearance of green areas and reduction in the natura has changed. Contemporary man observes that progressive pollution is the cause of increasingly numerous civilization diseases, and the shrinking of natura resources may have very negative impact for future generations. In addition, modern society has higher demands from a place of living and expects a better quality of life and a healthier environment. Open space for the benefit of the urban environment.
Realizację tego zadania wspiera rozwoj zrównoważony kalnej. Projektowanie zrównoważone wymusza potrzeb szerokiego spojzznia na aspeck kszatowania przestrzeni osiedlowej uwzględniającego elementy ekologii, zapewniającego dobre warunki do zycia i pracy oraz odpowiedni dobor programu funkcjonalnego.

Należy zwrocic uWage, że znaczny procent polskic miast stanowią osiedla wybudowanie $w$ technolog wielkopłytowej. Są to osiedla ciagle zamieszkałe oraz cieszące się zainteresowaniem wśród nowych nabyw ców. Nie ulega jednak wątpliwości, że ich stan odbiega od wspołczesnych norm, jak i nie odpowiada na potrzeby obecnego oraz przyszlego użylkownika, co sprowoprzysźści W Polsce prewazaja glosy preciw ich wyprzyszlosci. Wr polsce przewazaja glosy przeciw ich wyoraz zauwazia ich zalety, w zwiazu z czym koniecznym wydaje sie być podjecie dziotá w kierunku ich rehabilitaji Dodatkowo można wnioskować iz nie podejmuja działá rehabilitacyjnych, w przysztości najprawdopodobniej osiedla te ulegną całkowitej degradacji.

Problem modernizacji czy rehabilitacji osiedli z wielkie płyty poruszany jest w licznych publikacjach. Jan Maciej Chmielewski pisze: „Modernizacia zasobów mieszkaniowych jest działaniem przyczyniającym się zarówno do poprawy warunków mieszkaniowych, jak i sprzyja rozwiązywaniu problemów spotecznych [...] różnorodne działania rehabilitacyine prowadzone w skali całego osiedla [...] zapobiegają dewastacji osiedli i niszczeniu zasobu mieszkaniowego, ktorego następstwem moze być w wielu przypadkach konieczność podjęcia decyzi o wyburzaniu [...] Modernizacja osiedli mieści się rów niez w kanonach zrownowazonego rozwoju, stwarzając zarowno lepsze warunki mieszkaniowe dla przyszlych pokolen, jak i zapewniając bardziej przyjazne dla srodowiska przyrodniczego formy przystosowania go do potrzeb człowieka."

Zasada zrównoważonego rozwoju, mówiąca o zaspo kajaniu potrzeb współczesnego użytkownika, a zarazem dawaniu mozliwosci zaspokojenia potrzeb przyszłych pokoleń, jest jedną z podstaw stwierdzenia, że prze kształcania istniejących obiektów, w myśl tych zasad s dpowiednim i prystosciowym kierunkiem.

W celu sprecyzowania jak najlepszych kierunków rehabiltacji polskich osledll należy na bieżąco monitorowa

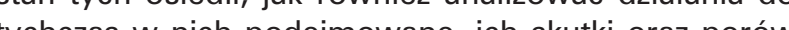
nywać je z dziataniami oraz skutkami przeprowadzanymi $w$ tym zakresie za granicami naszego kraju. ${ }^{3}$

\section{Działania rehabilitacyjne przeprowadzane w Polsce}

Zespoły wielkopłytowe cechuje dość monotonna urbanistyka oraz niezagospodarowane przestrzenie, które wymagają aktywizacji.

Do ważniejszych problemów z nimi zwiazzanych zaliczyć można braki funkcjonalno-użytkowe zwiazane m.in. $z$ infrastrukturą komunikacyjną. Początkowo dość dobre założenia rozwiązań komunikacyjnych, w wyniku upływających lat oraz znacznego zwiększenia się ilości samochodów, stały się nieczytelne oraz niedostosowan
It should be emphasised here that a significant percentestates. These are housing estates that are still inhabited and enjoy interest among new buyers. However, there is no doubt that their condition deviates from moder standards and does not meet the needs of the present and future users, which has triggered numerous studes aimed at determining their future. In Poland, the maJority is against their demolition. Many residents are attached to housing estates and see their advantages, so it seems necessary to take action to renovate them. In addition, it can be concluded that without any renovation measures, the housing estates will most probably be completely degraded in the future.

The upgrade or renovation of prefabs is discussed in numerous publications. Jan Maciej Chmielewsk writes: „Modernizacja zasobów mieszkaniowych jest działaniem przyczyniającym się zarówno do poprawy warunkow mieszkaniowych, jak isprzyja rozwiazywaniu problemów spolecznych [.... różnorodne dziatania rehabilitacyjne prowadzone w skali catego osiedla [...] zapobiegaja dewastacji osiedli i niszczeniu zasobu mieszkaniowego, którego następstwem może byc w wielu przypadkach konieczność podjęcia decyzil w wiburaniu [...] Modenizacja osiedi miesci sie rownież w kanonach zrównoważonego rozwoju, stwarzajac zarowno lepsze warunki mieszkaniowe dia przysztych pokolen, jak i zapewniając bardziej przyjazne dla srodowiska przyrodniczego formy przystosowania go do potrzeb czlowieka. "Modernisation of housing resources is a measure contributing both to he in rovenens of housing conditons and to the so-

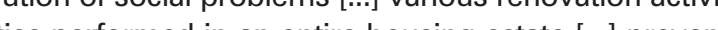
is perfor is devastation and destructon, which may, in many cases, resull in the need to demolsh hem [...] Mod-

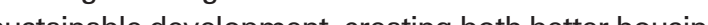
conditions for future genertions and more environchen The principle of sustainable devernent, which reThe to satisfying the needs of the contemporich reand future generations, is one of the grounds for the tatement that the tansormations of exing buidto these pinciples, are approprite and future-oriented.

To specify the best possible renovation measures of Polish housing estates, it is necessary to monitor their condition on an ongoing basis, as well as to analyse the actions taken so far, their effects and to compare them with the measures and effects implemented abroad.

\section{The renovation in Poland}

Large-panel complexes are characterized by quite Lonotons urban planning and undeveloped spaces that need revitalisation.

Major problems related to them include functional and usability deficiencies associated with, among others, communication infrastructure. Quite good 


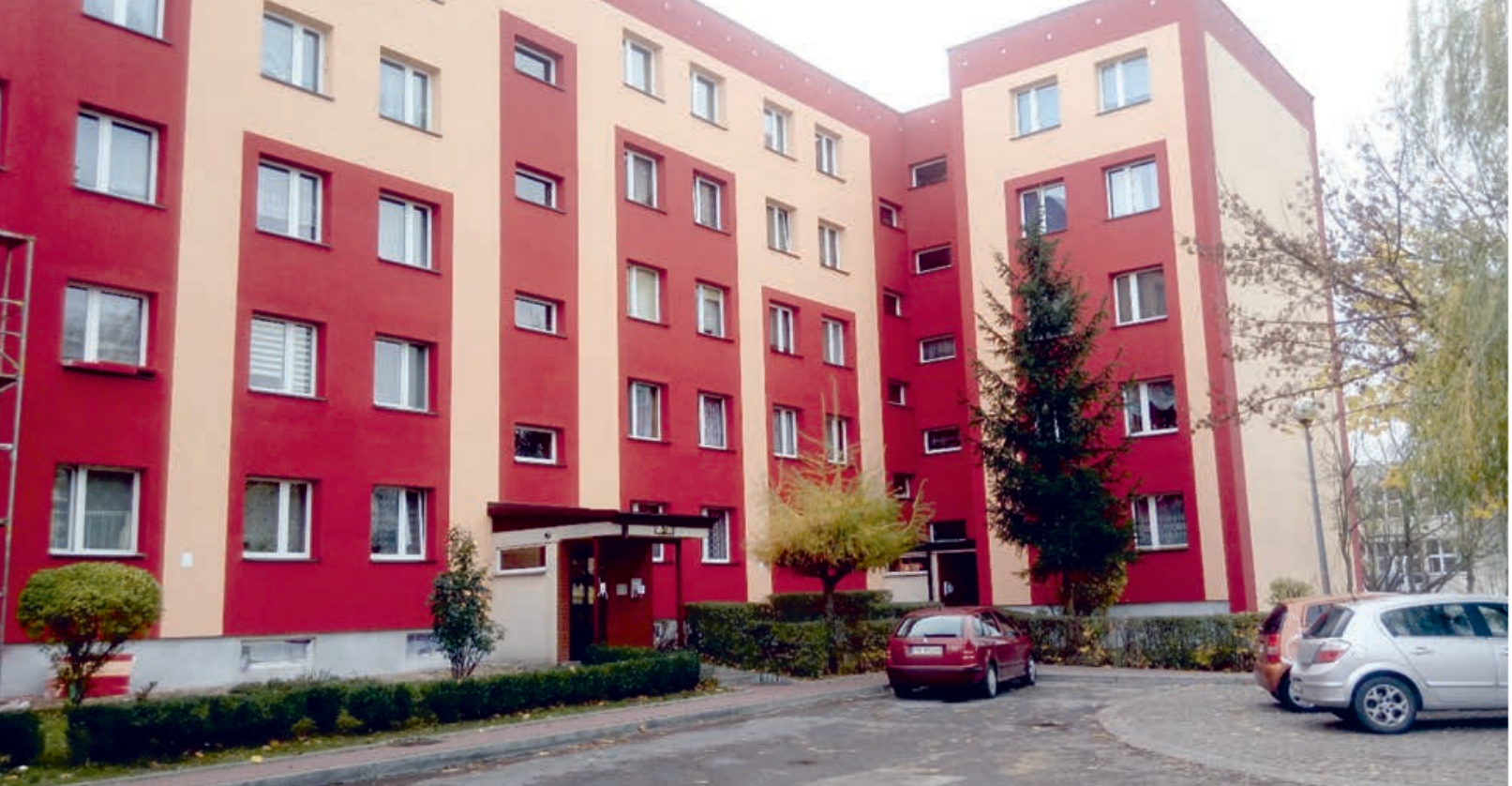

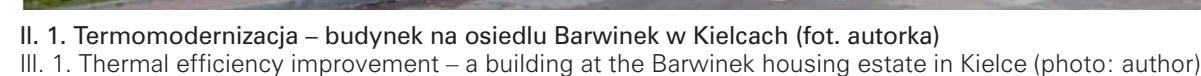

do współczesnych wymogów. Do najbardziej zauważalnych problemów osiedli z wielkiej płyty zaliczyć można samych budynków jak i przestrzeni wokót, brak ciekawie saksztattowanych terenów zielonych oraz niskie standardy mieszkaniowe.

Pomimo licznych wad zainteresowanie tego typu mieszkalnictwem nie spada, co potwierdzaja przeprowadzane w nich dzi honi poprajajce atrakcyjność oraz korygujące ich ważniejsze wady.

dernizacia (i. 1) re budynków to najczęściej termomodech $m$ min dzek oraz przeprojektowywanie strefy wejściowej do budynców w taki sosób, aby była bardziej bezpieczna oraz dostepna dla ośb niepenosprawnych.

Do działań w przestrzeni zewnętrznej zaliczyć można uzupełnianie $w$ sprzęt placów zabaw, budowa nowych placów zabaw (il. 2), zewnętrznych siłowni (il. 3) oraz

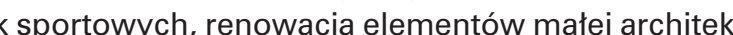
tury, w tym wymiana oświetlenia, ławek, koszy na śmieci

communication solutions initially have become unclear and inadequate to modern requirements as time passed and due to a significant increase in the number of cars. The most noticeable problems of prefabs include the lack of clear spatial arrangements, poor aesthetics of the buildings and the space around them, lack of interestingly developed green areas and low housing standards.

Despite numerous disadvantages, the interest in this type of housing does not decline, which is confirmed by the steps taken to improve its attractiveness and to correct the major flaws.

The most common measures within buildings is thermal efficiency improvement (III. 1), renovation of common areas in buildings, including staircases, replacement of floors and redesigning the entrance zone to buildings to make it safer and more accessible for people with disabilities.

Outdoor activities include equipping playgrounds with Oetra equipment construction of new plygrounds (III. 2), outdoor gyms (III. 3) and sports fields, renovation

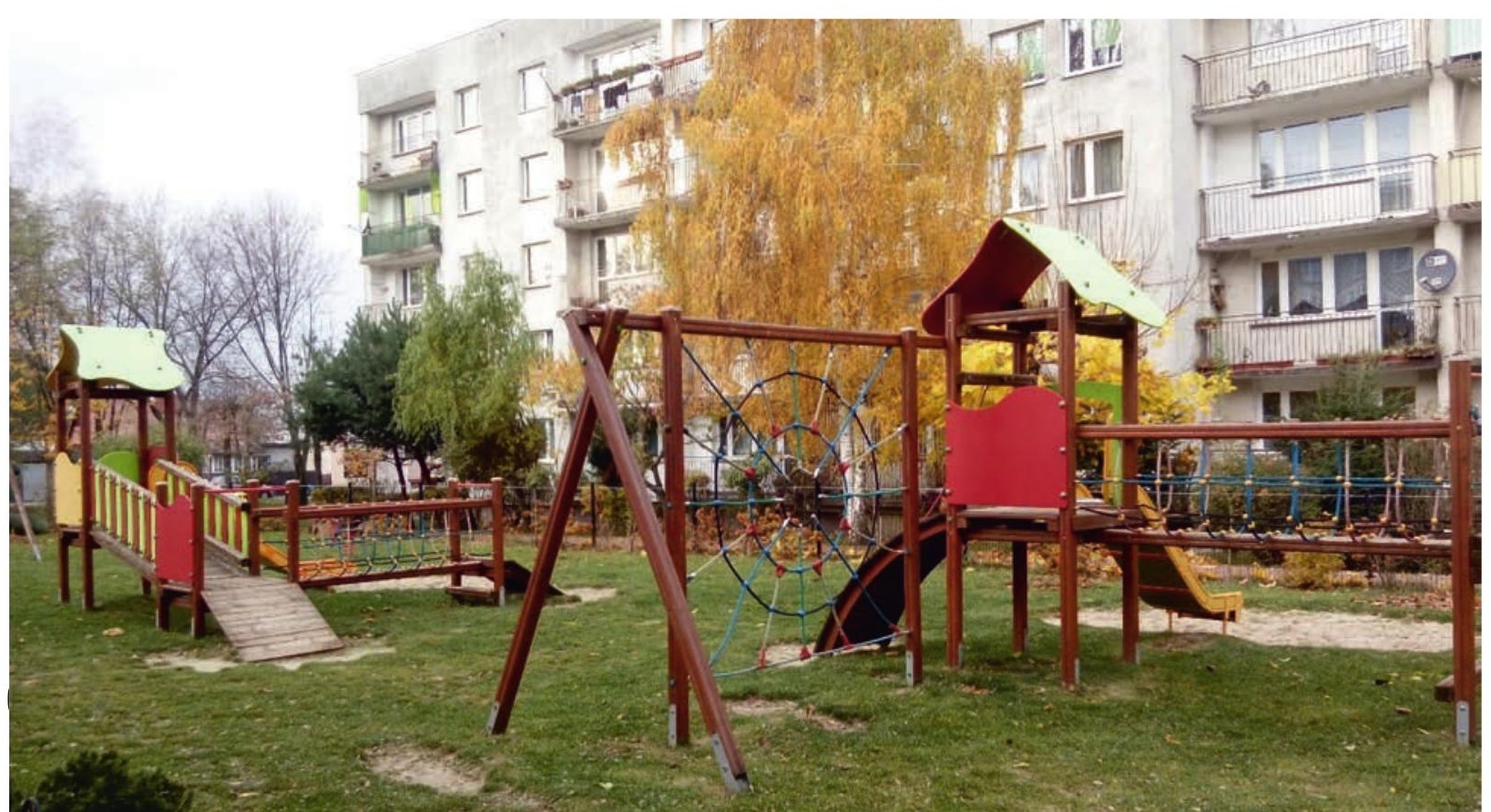

czy też nasadzenia zieleni, która pozytywnie wpływa na odbiór estetyczny przestrzeni.

Przekształcenia przeprowadzane w Polsce nie należa do kompleksowych, ale mają znaczacy wpływ na jakość życia Należy zauważyć, że przeprowadzane działania sa dobre i wpływają na poprawę komfortu życia w osiedlach, jednak poprzez brak kompleksowego podejścia mog okazać się niewystarczające, aby osiedla te przetrwały próbę czasu.

Poniżej scharakteryzowano 5 przykładów rehabilitaci obiektow z wielkiej plyty przeprowadzone za granica. Wybrane do analizy obiekty charakteryzuje obecnos elementow projektowania zrównoważonego w podejściu do ich przekształceń.

\section{PRZYKLAD 1}

Przebudowa pojedynczego obiektu biurowego - Ham burg, Bogenallee 12 (il. $4 \mathrm{i}$ il. 5 )

Lokalizacja: Hamburg, Bogenallee 10-12

Okres realizacji: 2003-2004

Przykład prezentuje przebudowę obiektu biurowego pochodzącego z 1974 roku na obiekt mieszkalny. ${ }^{4}$ Autoram projektu jest grupa Blauraum.

zynek znajduje się w mieszkaniowej części Hambura kalny. Na czterech pietrach zlokalizowano 15 mieszkróżego typu. Jak sie okazato nowy budynek w ideahy sposób wtopit sie w otocznie oraz spowodowat ożwie nie catej okolicy, jak i sprowokowat do podejmowania kolejnych działań modernizacyinych.

Budynek zostat rozebrany do skour

skorupy, nastepnie podda作 wadzic wygodne rozwiązania funkcjonalne. Najbardzie widoczne zmiany obserwujemy w elewacjach, jednak przekształcenia dotyczyły również układu konstrukcyjnego. Wynikały one ze zmian funkcjonalnych w obrebie pomieszczeń, jak i dobudowaniu do obiektu tzw. pudefek Flex oraz balkonów, które wymagały zastosowania dodatkowej stalowej konstrukcji, schowanej pod now drewnianą okładziną. W związku z powyższym wszyst- of street furniture, including replacement of lighting, benches, rubbish bins or planting green areas, which positively affects the aesthetics of the space. Transformations implemented in Poland are not complex, but have a significant impact on the quality of life. It should be noted that the measures are good and improve the quality of life in housing estates, but the lack of a comprehensive approach may not be sufficient to make them stand the test of time.

Below are 5 renovation examples of large-pane buildings implemented abroad. The buildings selected for analysis are characterized by the presence of sustainable design elements in the approach to their transformation.

\section{Example 1}

Conversion of a single office building - Hamburg, Bogenallee 12 (III. 4 and

Location: Hamburg, Bogenallee 10-12

mplementation period: 2003-2004

The example shows the conversion of an office building from the year 1974 into a residential building The authors of the design is the Blauraum group. The building is located in the residential part of Hamburg. Lack of justification for the further use of the into a resident bilding. On four floors there are 15 a residents building. On fur floors the are an and revived the entire area as well as triggered fur ther modernization.

The building was dismantled to a shell and then comwed in an effort to introduce convenie functional solutions. The most visible changes can be seen in the façades, but the transformations also covered the structural system. They resulted from functional changes within the rooms, as well as the addition of the so-called Flex boxes and balconies to the building, which required the use of additiona steel structure, hidden under the new wooden clad ding. As a result, all apartments were provided with 


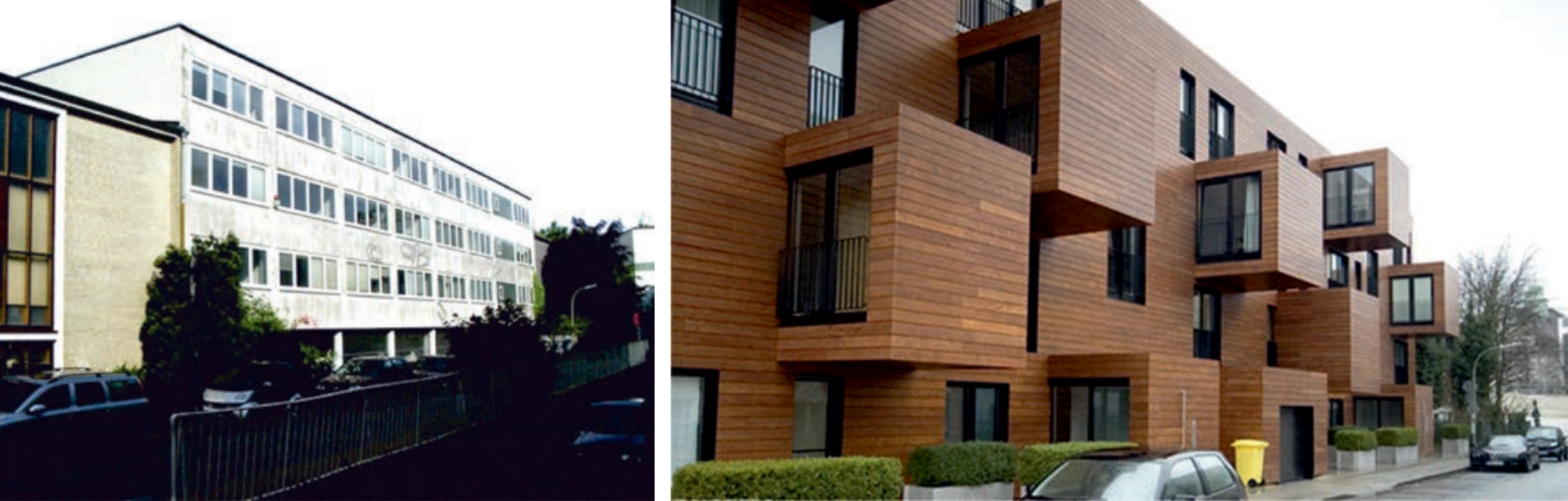

II. 4. Budynek biurowy przy Bogenallee 12 przed rehabilitacia (źródło: http://www.bryla.pl/bryla/1,85298,6437379,Pozytywna_modernizacja

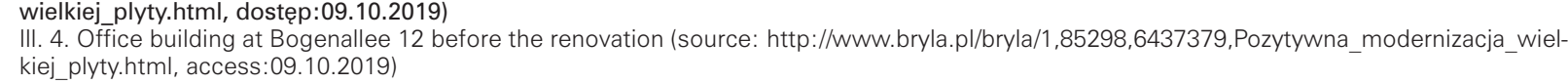

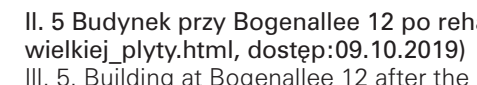
1II. 5. Building at Bogenallee
htmi, access: 09.10 .2019$)$

kie mieszkania uzyskały od strony dziedzińca obszerne balkony, natomiast od elewacji frontowej powiększona została powierzchnia mieszkania. Wspomniane Pudefka Flex nadaja charakterystyczny nowoczesny charakter całej bryle, a dodatkowo stanowią w zależności od mieszkania salon, jadalnię bądź sypialnię. Mieszkania zlokalizowane na parterze od strony dziedzińca poprzedzone są patio.

Przekształceniom poddano również strefę wejściowa do budynku, gdzie zaprojektowano donice z zielenia. $W$ projekcie zastosowano nowoczesne materiały, jak stal czy drewno.

Obecnie obiekt sprawia bardzo dobre wrażenie oraz nie odbiega standardem od współczesnej mieszkaniówki.

\section{Przykład 2}

Rehabilitacja budynku w Halle

Lokalizacja: Halle (Salle), Halle-Neustradt, przy ulicy Oleanderweg 21, Niemcy

Okres rehabilitacji: 2008-2010

Projektanci: Stefan ForsterArchitekten ${ }^{6}$

Rehabilitacja budynku w mieście Halle prezentuje przekształcenia w obrębie jednego obiektu. (il. 6 i il. 7) Obiek został zmniejszony poprzez wyburzenie części ostatnie kondygnacji co wpłynęło na zburzenie monotonii elewacji typowego budynku z wielkiej płyty. Górne mieszkania pozostawiono w co drugiej klatce, natomiast $w$ prze-

sacious balconies on the yard side, while the front elevation was enlarged. The mentioned Flex Boxes give a characteristic modern character to the entire building shell and in addition, serve as a living room, dining room or bedroom, depending on the aparment. Flats located on the ground floor from the yard side are preceded by a patio.

The entrance zone to the building, with green pots, was also converted. The design features modern maerials, such as steel and wood.

Currently, the building makes a very good impression and does not differ from the standard of a moder residential building

\section{Example 2}

Renovation of a building in Halle

Location: Halle (Salle), Halle-Neustradt, Oleanderweg 21, Germany

Renovation period: 2008-2010

Designers: Stefan Forster Architekten ${ }^{6}$

The renovation of the building in the town of Halle shows the transformations within a single building. (III. 6 and 7) The building was reduced by demolishing a part of the top floor which eliminated the monotony of the typical large-panel building façade. Upper flats were left in every second staircase enclosure, while the spaces created after the demolition, gained terraces with gardens. Six out of eleven

II. 6. Haus 8 Leinefelde - stan przed rehabilitacja (źródto: https://www.sfa.de/regeneration-east/haus-08-en, dostepp: 10.10.2019)
III. 6. Haus 8 Leinefelde - condition before the renovation (source: https://www.sfa.del/regeneration-easthaus-08-en, access: 10.10.2019)

II. 7. Haus 8 Leinefelde - stan przed rehabilitacia (íródto: https:///www.sfa.de/regeneration-east/haus-08-en, dostep: 10.10.2019)
II. 7. Haus 8 Leinefelde - condition after the renovation (source: https://Www.sfa.del/regeneration-east/haus-08-en, access: 10.10.2019)
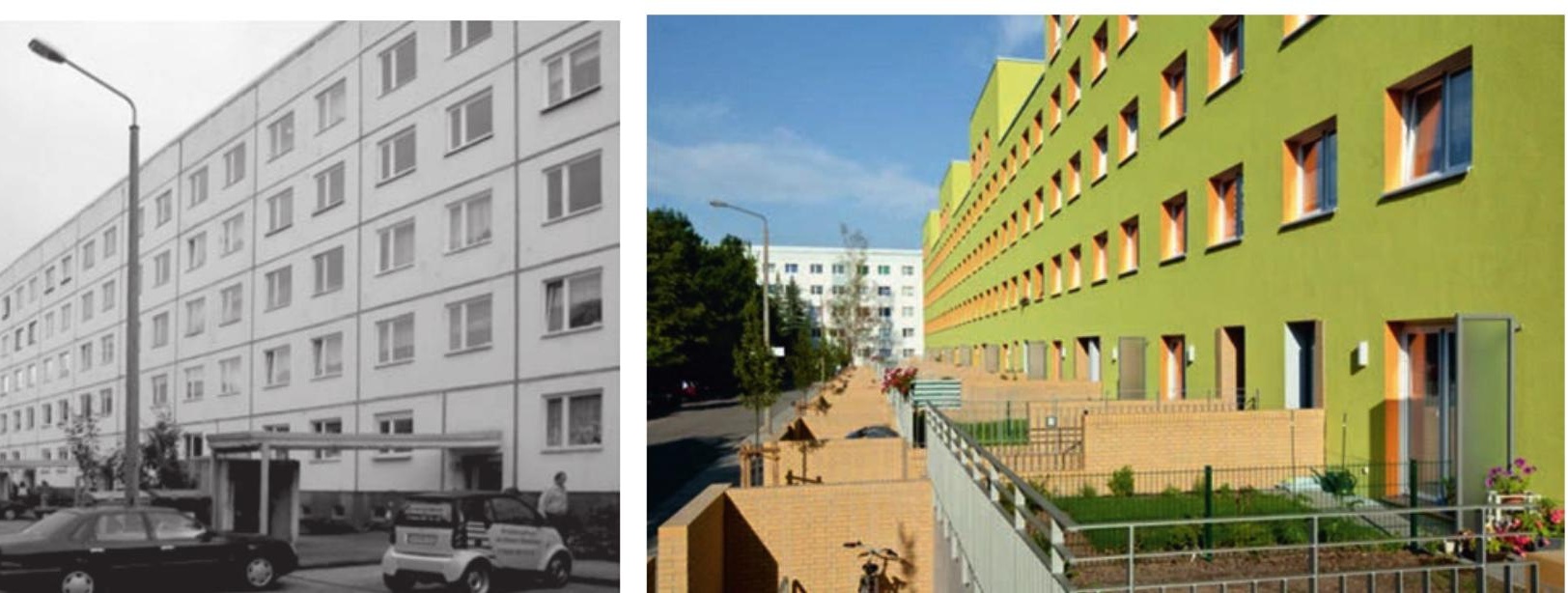

strzeniach powstałych po wyburzeniach zaplanowano tarasy z ogrodami. Pozostawiono szesc z jedenastu klatek schodowych. Od strony podworka dobudowano duze balkony, a także przeprojektowano strefę wejsciowa. Elementem charakterystycznym są okalające wejścia murk z klinkieru oraz posadzona tam zieleń. Zabiegi te wpłynęly na poprawę bezpieczenstwa, umożliwily lepszą orientacj w przestrzeni oraz zaakcentowaly wejscia do kolejnych klatek. Rozległe ogrody w parterach od strony podwórk wpłynęły na lepsze relacje wnętrza obiektu z zewnętrzem. W elewacji budynku zastosowano intensywny żótty kolo natomiast podstawa obiektu zbudowana $z$ jasnej okładzi ny klinkierowej wprowadza harmonię w elewacji. Zmian dokonano również wewnątrz obiektu. Między innym zredukowano liczbę mieszkan, poprawiając zarazem ich

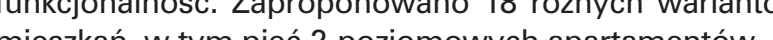
mieszkań, w tym pięć 2-poziomowych apartamentów.

Przykład 3

Rehabilitacja bloków mieszkalnych w Leinefelde

Lokalizacja: osiedle w Leinfelde, Niemcy (il. 8 - il. 14))

2001-2006 (Haus 1, 1999; Haus 2 Stad 7 illen $7-8,2004$; Haus 6 -Stormstrass $14-28$, 2007) Projektanci: Stefan Forster

Przykład prezentuje przeksztatcenia w obrebie kilku bu Prynków których autorem jest pracownia Stefan Fo buArchitekten?. Prawie wszystkie przebudowy bloków za kładały redukcje wysokości z 6 na 4 kondygnacje, dziek czemu obiekty nabrały indywidualnego charakteru oraz zyskały cechy niskiej intensywnej zabudowy mieszka niowej, a powstałe miedzy nimi przestrzenie lepiej odpowiadają skali człowieka. Budynki dzięki nowej formie staty się punktami charakterystycznymi dla osiedla i miasta. Monotonia elewacji została zburzona poprzez wycinanie części budynków, dobudowywanie obszernych balkonów, wprowadzenie tarasów na wyższych kondygnacjach oraz interesujących zróżnicowanych rozwiazzan strefy wejściowej do obiektów. Obiekty pomimo intensywnych kolorów użytych w elewacjach mają dość minimalistyczną oraz estetyczną w odbiorze formę. We wszystkich realizacjach wprowadzono działania umożliwiające lepsze relacje z otaczającym krajobrazem oraz zabiegi poprawiające bezpieczeństwo strefy wej-

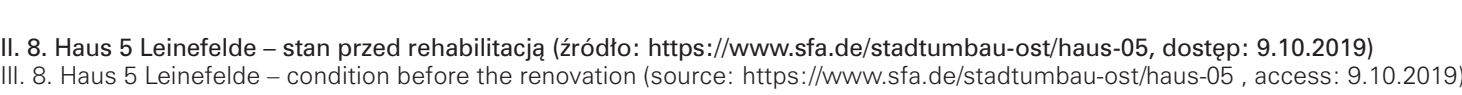

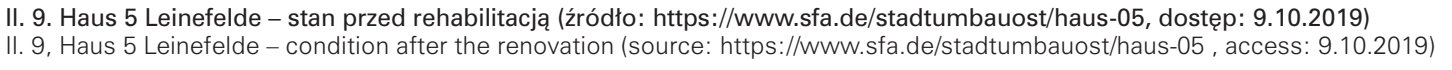

taircase enclosures were left. Large balconies were added from the yard side and the entrance zone was edesigned. The characteristic elements are the clinker walls surrounding the entrances and the greenery planted there. These measures improved safety, act Ext the entrances to the next staircase enclosures. Extensive gardens on the ground floor from the yard ide improved the interconnection between the inteior and exterior of the building. An intense yellow colour was applied to the building façade, while the ( wroduces harmony into the façade. The changes were also made inside the building. Among other were a the number of apartments was reduced and tir functionality improved. Eighteen different vari-

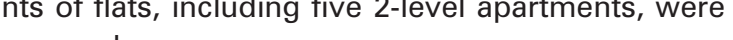
proposed.

3 8-14) Renovation period: 2001-2006 (Haus 1, 1999; Haus , 2001; Haus 3, 2002; Haus 4, 2003; Haus 5, 2006; 14-28, 2007)

Designers: Stefan Forster ' reconstructions of the blocks assumed a reduction in ge gained an individual character and the feacres of low housing development, and the spaces created between them better correspond to the human scale. Thanks to the new form, the buildings the city.

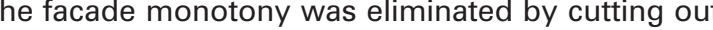
parts of the bulldings, adding large balconies, in-

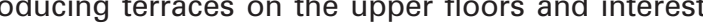
ing diversified solutions of the entrance zone to the buildings. Despite the intense colours used in the fa-

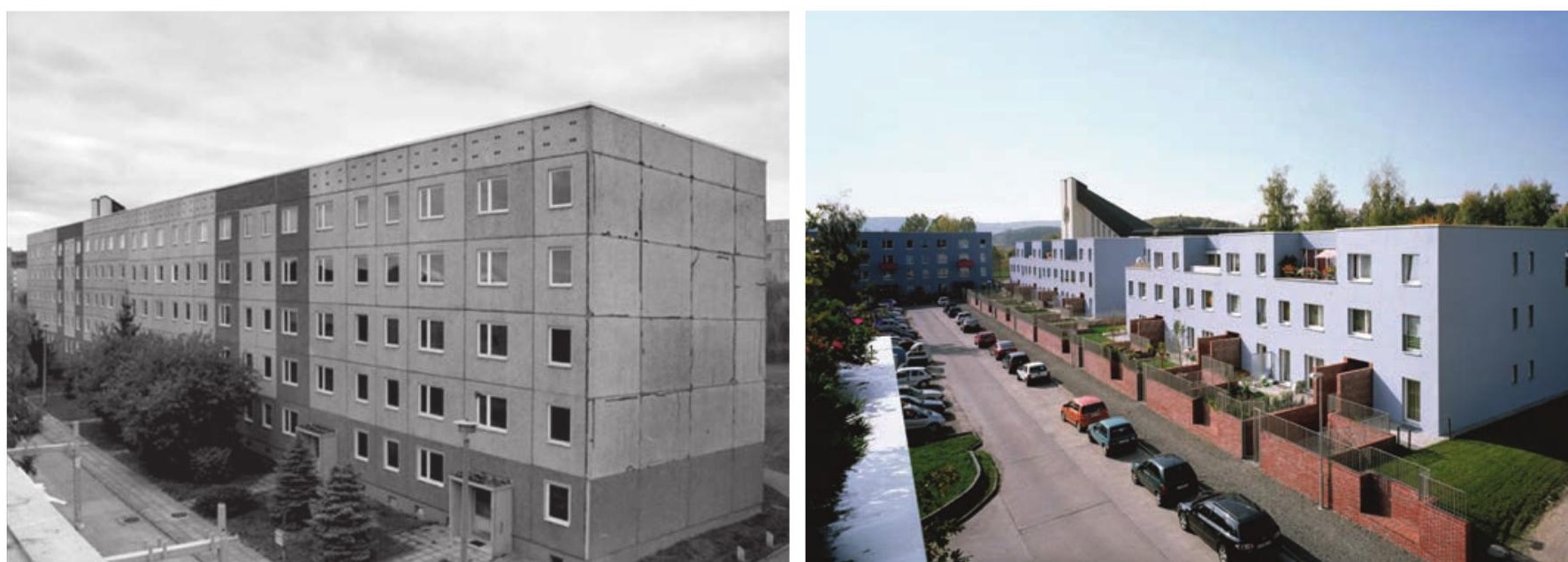


układanych jeden nad drugim. Głębokość modułów wynosita $3,8 \mathrm{~m}$. Tym sposobem uzyskano duże tarasy połaczonez salonem, do którego moźna przejśc przez oszklone przesuwne drzwi. Dodatkowo w budynkach wymienion instalację elektryczną, zamieniono okna na większe, zamontowano nowe windy oraz pomalowano elewacje. Projekt otrzymal pierwszą nagrodę nadaną przez kapitułę Nagrody Unii Europejskiej im. Miesa van der Rohe.

\section{Podsumowani}

Polskie osiedla z wielkiej płyty nie podlegaja tak szybkiej degradacji, jak osiedla np. w Europy Zachodniej. Pomimo to pod względem architektonicznym, technicz nym, czy też estetycznym odbiegają one współczesnych W Polsce trwaja dysusie na temat przyszłości tegego. dzaju zespotóc Studiujc liczeje publikacie wo tym tomcie zaumażć moina, iż istnieje tendencja ku ich rehabilitowaniu $Z$ daniem atorki ma to zwiazek z cialym zainteresowaniem nimi wśród nowych nabywców Rehabilitacja obiektów oraz zespotów wielkopłytowych powinna zmierzać do dostosowania ich do wspótczesnych tendencii oraz zasad zrównoważonego rozwoju. Poddane jej osiedla umożliwiać powinny różnorodne relacje z otaczającym krajobrazem i natura oraz tworzyc odpowiednie warunki dla życia rodziny.

Powyżej omówione zostały cztery przykłady rehabilitacij obiektów wybudowanych w technologii wielkopłytowe w których uwzględniono zasady projektowania zrównoważonego, dażące do poprawy jakości życia oraz stworzenia odpowiednich warunków dla życia użytkowników. W większości przytoczonych przykładów przeprowadzone działania zmierzały do poprawy relacji wnętrza $z$ zewnętrzem oraz zapewnienia otwarc widokowych $n$ otaczający krajobraz. Założenie to udało się osiągnąc poprzez wprowadzenie duzych otworów okiennych, tarasow, obszernych balkonow w w mieszkaniach na wyższych kondygnacjach oraz ogrodów w parterze. Zaproponowa ne w obiektach ogrody, balkony, czy tarasy bez problem mogą konkurować z przydomowymi ogródkami.

Charakterystyczną cechą obiektów z wielkiej płyty jes monotonia rozwiązania elewacji. Przytoczone powyże przykłady prezentują rozznorodne działania zmierzające do jej przerwania. Do najbardziej radykalnych należą częścio we wyburzenia oraz wprowadzanie zielonych przestrzeni na wyższych kondygnacjach. Do mniej radykalnych elementów przestrzenych, stanowiacych zarazem powiekszenie przestrzeni mieszkań (budynek w Bogenalle, pudetka Flex), czy tez zastosowanie nowoczesnych ma teriatów i detalu architektonicznego (drewno w elewacil budynek w Bogenalle). Na zburzenie monotonii elewaci wpłyneto również przeprojektowanie stref wejściowych do obiektów, które stały się elementami charakterystycz nymi każdego obiektu. Wprowadzono różnice terenu oraz zastosowano zieleń w taki sposób, aby strefa wejściowa zyskała cechy przestrzeni półprywatnej, a zarazem br dziej bezpiecznej. Dodatkowo kolorystyka analizowanyc obiektów tworzy spójną oraz estetyczną kompozycje. Wartym uwagi jest również ostatni z przytoczonych przykładów, mianowicie rehabilitacja 3 bloków we Francji.
Europe. Nevertheless, in terms of architecture, engiPoland, there are ongoing discussions on the future of this type of complexes. While studying numerous publications on this subject, one can notice that there is a tendency towards their renovation. According to the author, this is related to the constant interest in them among new buyers.

Renovation of large-panel buildings and complexes should aim to adapt them to modern trends and the principles of sustainable development. The housing estates undergoing renovation should bridge the surrounding landscape and nature and create approprate conditions for a family life.

The four examples of the renovation of large-pane buildings are discussed above, which include the principles of sustainable design aimed at improving the quality of life and creating appropriate living conditions for residents.

In most of the cited examples, the implemented measures were aimed at improving the correlation between the interior and the exterior and a ensuring that the view is open to the surrounding landscape. This was achieved by introducing large window openings, terraces, large balconie in apartments on the upper floors and gardens on the ground floor. Gardens, balconies or terraces proposed in the buildings can easily compete with home gardens.

A characteristic feature of large-panel buildings is the monotony of the façade. The above examples present various measures to change it. The most radica are partial demolitions and the introduction of green include, among others, the addition of spatial efeinclud a apartments (the billing in Bogenter Fex boxest, or the application of moden materials and a hitect, cetails (mod in the facade, the bulding in Bogente). The rodesign of the entrance 20 ines to the builings, which became characteristic elements of each builing eliminted the monotony of the facade. Torrain differences were introduced and green area was applied in such a way that the entrance zone gins the features of semi-private space and more secure at the same time In addition, the colours of the analyzed builings create a cont tent and aesthetic composition.

The last of these examples, namely the renovation 3 blocks of flats in France, is also worth emphasing here. The example shows the enlarged living space by adding prefabricated elements to the facade of the building without the need to relocate the residents. This is a noteworthy and innovative approach to the renovation of such buildings.

The proposed solutions are very attractive. The question arises, however, to what extent these designs are possible in Polish conditions, where the financia barrier is a significant problem now
Przykład prezentuje powiększenie przestrzeni do życia poprzez dobudowywanie prefabrykatów do elewacji obiektu bez potrzeby przesiedlania mieszkajacych w budynkach ludzi. Jest to godne uwagi oraz innowacyjne podejście do rehabilitacji tego typu obiektów.

Proponowane rozwiązania są bardzo atrakcyjne. Pojawia się jednak pytanie, na ile realizacje te są możliwe w polskich warunkach, gdzie niebagatelnym w tym momencie problemem jest chociażby bariera finansowa. Mimo to pojawiaja się głosy, żeby nigdy nie niszczyć, a dodawać i przekształcać oraz, że takie działanie może być nawet trzykrotnie tańsze od wyburzania.

Biorąc pod uwagę ciągły proces degradacji obiektów z wielkiej płyty można wyciągnąć wnioski, iż nie podejmując radykalnych dzialan, osiedla te zaczną, pustoszec, a następnie

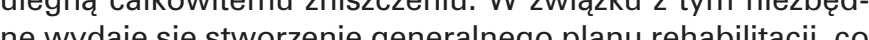
re wyaje sié stworzenie generalnego planu rehabítacji, co wadzanych za granicami kraie pod

Jrzykładów wynika, że uwzglednienie zasad zrównoważonego rozwoju podczas prac rehabilitacyinych jest dobrym oraz przyszłościowym kierunkiem przeksztatceń obiektów oraz zespotów wybudowanych $w$ technologii $z$ wielkiej płyty.

PRZYPISY

J.M. Chmielewski, Modernizacja osiedli mieszkaniowych", Oficyna Wydawni-

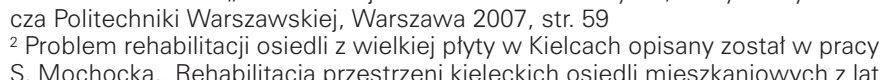

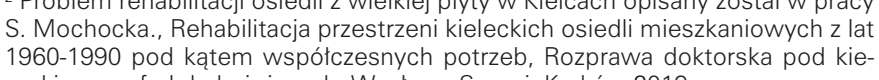
unkiem prof. dr hab. inż. arch. Wactawa Serugi, Kraków 2019
http://www.brylla.pl/bryla/1,85298,6437379,Pozytywa_modernizacja wielkiejplyty.html dostep: 09.10 .2019
shttp://www.blauraum.eul/projekte/project/2/ dostep: 09.10 .2019

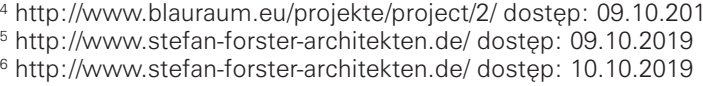

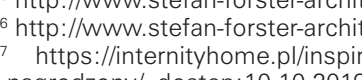

LITERATURA

[1] Mochocka S., Rehabilitacia przestrzeni kieleckich osiedli mieszkaniowych z lat
$1960-1990$ pod katem wspotczesnych potrzeb, Rozprawa doktorska pod kierun-

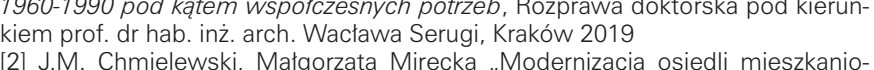
[2] J.M. Chmielewski, Matgorzata Mirecka, "Modernizacja osiedli mieszkanio-
wych", Oficyna Wydawnicza Politechniki Warszawskiej, Warszawa 2007

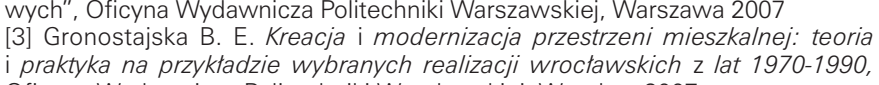

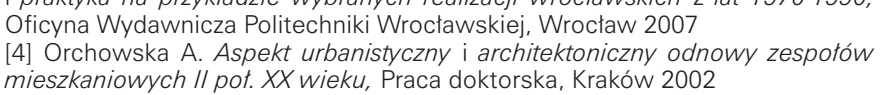
ŻRÓDLA INTERNETOWE

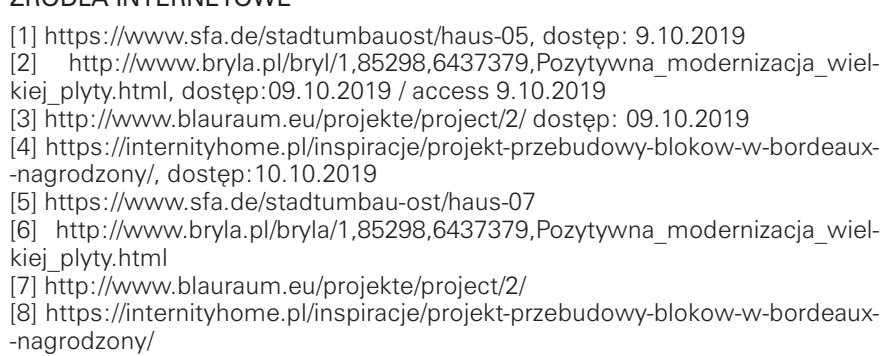

less, there are opinions never to destroy, but to add and to transform, and that such measure can

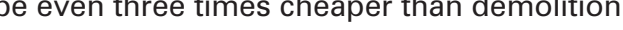
Taking into account the continuous degradation process of the prefabs, it can be concluded that Whout taking any radical action, these settle-

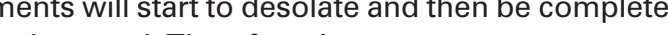
ly damaged. Therefore, it seems necessary to cre-

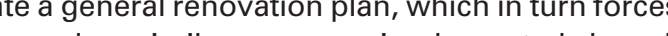
in and examples the principles forstopment during renovation tronsformation of large-panel buildings and complexes.

ENDNOTES

J.M. Chmielewski ,Modernizacia osiedli mieszkaniowych"
Oficyna Wydawnicza Politechniki Warszawskiej, Warszawa 2The problem of renovation of prefabs in Kielce was described
kieleckich osiedli mieszkaniowych. z lat $1960-1990$ pod katem wspótczesnych potrzeb, Doctoral thesis under the direction of
prof. dr hab. inz. arch. Wactawa Serugi, Kraków 2019

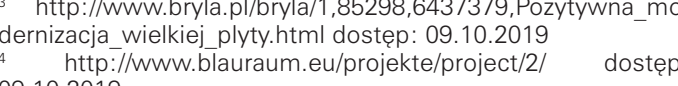
19 w.stefan-forster-architekten.de/ access: 09.10.20

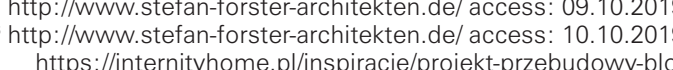
https://internityhome.pl/inspiracie//projekt-prz:
kow-w-bordeaux-nagrodzony/, access: 10.10 .2019

\section{REFERENCES}

1] Mochocka S., Rehabilitacia przestrzeni kieleckich osiedlh
mieszkaniowych z lat 1960-1990 pod katem wspótczesnych Inz. arch. Wactawa Serugi, Kraków 2019
[2] J.M. Chmielewski, Matgorzata Mirecka „Modernizacia
osiedili mieszkaniowych", Officyna Wydawnicza Politechnis osiedli mieszkaniowych", Oficyna Wydawnicza Politechnil
Warszawskie, Warszawa 2007

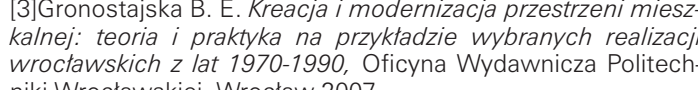
niki Wroctawskiej, Wroctaw 2007
[4] Orchowska As Aspekt urbanistyczny iarchitektoniczny odno-
wy zespotón mieszkaniowych II pot. XX Wieku, Doctoral thesis, Krakespotów m 2002

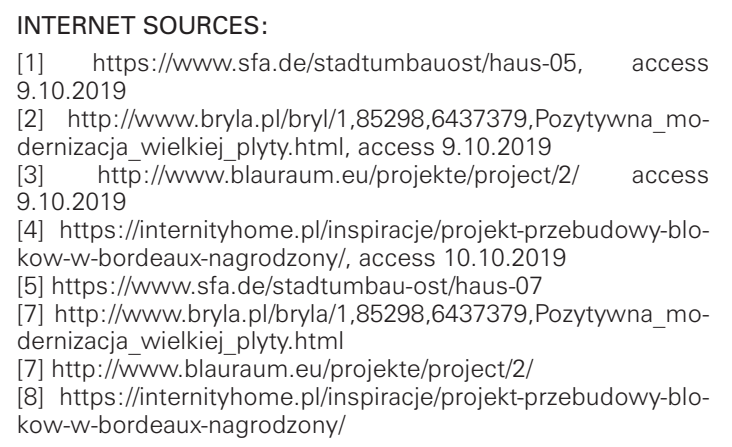

